\title{
Acceptability of improved Cassava varieties by Cassava processor in Akinyele Local Government Area Oyo State.
}

\author{
Olayemi, O.O. ${ }^{1}$, Ajanaku, A.O ${ }^{1}$, Babatunde, R.O ${ }^{1}$. and Bashir, I.D. ${ }^{1}$ \\ ${ }^{1}$ Department of Agricultural Extension and Management, Federal College of Forestry, Ibadan, Oyo State. P.M.B.5087 \\ bodecrespo1@yahoo.co.uk 08054035443 \\ DOI: 10.31364/SCIRJ/v6.i11.2018.P1118584 \\ http://dx.doi.org/10.31364/SCIRJ/v6.i11.2018.P1118584
}

\begin{abstract}
The acceptance of improved cassava varieties in any locality at any given time as a result of the interaction factors, lead to learning about the acceptability of improved cassava varieties in general becomes imperative in order to understand the pathways to acceptability. This study revealed the acceptability of improved cassava varieties by cassava processor in Akinyele Local Government Area Oyo state. Multi stage sampling techniques was used, $50 \%$ of the ward in the local government was purposively selected. List of registered cassava processor in selected wards was obtained from department of Agriculture and health in Moniya, purposively 50\% of cassava processor was selected to give 110 as sample size for the study. The Socio-economic characteristics of the respondents were examined, the respondents source of information on improved cassava varieties, constraints that militating against respondents acceptability and level of acceptability of improved cassava varieties. Frequency and percentage distribution were used to describe the data from Socio-economic characteristics and chi - square and Pearson product moment Correlation (PPMC) were also used to analyzed the data. The result revealed that $\mathbf{7 8 . 2 \%}$ of the respondents had the information source from relative and friends, radio and seminars /workshop. Also $61.8 \%$ of the respondents had high respond based on constraints against acceptability. While level of acceptability is low with 61.0\%. Chi - square analysis shows that there is no significant relationship between Socio-economic characteristics and acceptability of improved cassava varieties. Also PPMC analysis shows that there is significant relationship between source of information and acceptability ( $r=0.245$, $\mathbf{p}=\mathbf{0 . 0 . 1 0}$ ).Based on the empirical findings of the study, it could be deduced that respondents acceptability is very low. This may likely to high constraints encountered. It is therefore recommended that government and NGO in charge of improved cassava varieties need more awareness to the respondents in the study area as to improved their productivity.
\end{abstract}

Keywords: Cassava processors, Acceptability, Improved cassava varieties.

\section{INTRODUCTION}

Cassava (Manihot esculenta Crantz) is a starchy root crop that belongs to the family euphorbiaceae and grown widely in West Africa. Nigeria is currently the largest producer of cassava in the world with an annual output of 54 million tones of tuberous roots [6]. The crop has become a basic raw material for many small scale businesses such as cassava flour mills, bakeries, fast food firms, restaurants, gari processing firms and is currently an income generating activity [8]. Cassava production has been increasing for the past 20 years in area cultivated and in yield per hectare [4].

It had been suggested that before modern research on cassava started in Nigeria in 1954 at the FDAR, Ibadan, there were numerous local ecotypes of traditional clones. These varied in their tuber yields and general tolerance of prevailing pests and diseases. "Oloronto" (53101), a local cultivar from the Ibadan/Abeokuta area, was then recommended for southwestern Nigeria. It was later used in crosses in 1967 which led to the release of improved varieties such as 60444, 60447 and 60506 for the whole country.

In Nigeria for instance, cassava root and leaves do not only serve as an essential source of calories but as a major source of income for rural households. Cassava provides food and income to over 30 million farmers and large numbers of processors and traders in Nigeria [1]. Technological improvement (such as improved cassava varieties) is the most important factor in increasing agricultural productivity and reduction of poverty in the long-term [10]. 
The acceptance of improved cassava varieties in any locality at any given time is as a result of the interaction of various factors, including certain personal characteristics [9].There are some constraints facing the rural cassava processor adoption of cassava varieties which include failure of extension workers to reach them, lack of incentive to increase productivity, limited access to credit inputs, lack of access to relevant technological information and, and lack of access to membership in cooperatives and other rural organizations.

Cassava processors are almost entirely responsible for processing cassava which provides them with additional income earning opportunity and enhances their ability to contribute to household food security.

There is therefore the need to initiate studies the constraint that affects the acceptability of improved cassava varieties by cassava processor in the area. This will enable the cassava processors to confidently accept the improved cassava varieties for optimum and better cassava product.

\section{Specific objectives}

The specific objectives of this study include to:

i. describe the socio-economic characteristics of cassava processor using improved cassava varieties in the study area.

ii. describe the respondents' level of acceptability of improved cassava varieties among cassava processor in the study area?

ii. describe the constraints militating against acceptability of improved cassava varieties in the study area.

\section{Hypothesis of the study}

The hypothesis stated in the null form is tested:

$\mathbf{H}_{01}$ : There is no significant relationship between selected socio economic characteristics and acceptability of improved cassava varieties among cassava processor in the study area.

\section{Materials and Methods}

The study was carried out in Akinyele Local Government with the Administrative Headquarters located at Moniya. The Local Government shares boundaries with Afijio Local Government to the north, Lagelu Local Government Area to the east, Ido Local Government Area to the west and Ibadan North Local Government Area to the south. It occupies a land area of 464.892 square kilometers with a population density of 516 persons per square kilometer. The economy of the L.G.A. is endowed with fertile agricultural land suitable for the cultivation of crops like orange, mango, banana, pineapple, cassava, yam etc. which is based on the agriculture and the major occupation of the rural people is farming.

\section{Sampling Procedure and Sample size}

A Multi-stage sampling procedure was used to select respondents for the study. Out of 33 Local Government Area in oyo state, Akinyele local government area is purposely select. Purposive sampling technique was used to selected 50\% wards/communities that were predominantly noted for cassava production from 12 wards in Akinyele local government area oyo state. List of registered cassava processors in selected communities was collected from the Department of Agric. and Health at the Local Government Headquarters in Arowomole and Eruwa respectively. 50\% of registered Cassava Processors in selected communities was randomly selected and gives a total of one hundred and ten (110) respondents that was used for the study. 


\section{Analysis of data}

Data collected were subjected to descriptive and inferential statistical analysis using statistical package for the social science (SPSS). Descriptive statistical tools used included frequency counts, mean and percentage while inferential statistical used is Chi-square.

\section{Results and Discussion}

\section{Socio-economic characteristics of respondents}

The mean age of all the respondents was 46.8. This implies that most of the respondents are in their active ages and this agrees with the finding of [7] who reported that perception and acceptability of innovation is mainly associated with youthful and active age of the farmers. It is also in line with [10] who reported that (92\%) of the cassava processors interviewed were between 21 and 60 years old. Results of analysis on respondents' sex in Table 1 revealed that $14.5 \%$ are males while $85.5 \%$ were females in the study area. This implies that females are more predominant in cassava processing than males in the study area. It also in line with [5] that says women contribute about $58 \%$ of the total agricultural labour in the Southwest, $67 \%$ in the Southeast and $58 \%$ in the central zones of Nigeria.

Result further revealed that $(27.3 \%)$ of the respondents had no formal education, $(59.1 \%)$ had primary education certificate, $(11.8 \%)$ had secondary and $(1.8 \%)$ had tertiary education. This implies that they need more enlightenment from extension agents on the importance of the improved cassava varieties. [11] Confirmed that education influences people's perception and acceptability of innovations. Furthermore the result also showed that household size of the respondents 1-4 were (40\%) while 5-8 were (60\%). This is similar to [2] who reported an average household size of 7 persons. This implies that the larger the household size the more labour availability and the more income requirement to meet household needs. The result further above shows that (81.8\%)of the respondents had processing experience of between 1-10 years, $13.6 \%$ had processing experience of between 11-20 years , while (4.6\%) and (0\%) had processing experience of between 20-30 and between 31-40 years, respectively. This is in agrees with the findings of [3] who asserted that farmers with long years of farming experience would be conversant with the constraints and this would increase their level of acceptance of new ideas as means of overcoming their production constraints.

Table 1: Socio-economic characteristic of the respondents

\begin{tabular}{|c|c|c|}
\hline Variables & Frequency & Percentage \\
\hline \multicolumn{3}{|l|}{$\overline{\text { Age }}$} \\
\hline $21-30$ & 7 & 6.4 \\
\hline $31-40$ & 56 & 50.9 \\
\hline $41-50$ & 47 & 42.7 \\
\hline \multicolumn{3}{|l|}{ Sex } \\
\hline Male & 16 & 14.5 \\
\hline Female & 94 & 85.5 \\
\hline \multicolumn{3}{|l|}{ Education status } \\
\hline No formal education & 30 & 27.3 \\
\hline Primary education & 65 & 59.1 \\
\hline Secondary education & 13 & 11.8 \\
\hline Tertiary education & 2 & 1.8 \\
\hline \multicolumn{3}{|l|}{ Household size } \\
\hline $1-4$ & 44 & 40.0 \\
\hline \multicolumn{3}{|c|}{$\begin{array}{l}\text { www.scirj.org } \\
\text { cientific Research Journal } \\
\text { 1364/SCIRJ/v6.i10.2018.P1118584 }\end{array}$} \\
\hline
\end{tabular}


$5-8$

9 and above

Processing experience (year)

1-10

$11-20$

Total

Source field survey, 2018

\section{Respondents' Level of acceptability on improved cassava varieties}

By categorization of level of acceptability in table $2 \mathrm{~b}$ showed that the level of acceptability of improved cassava varieties is low 61.0\% in the study area. Majority only accepted Molekanga and TMS01412 (100.0\%), (89.1\%) accepted Yellow cassava, NR03/0211, black cassava and IITA-TMS-L982132, (80.0\%) accepted IITA-TMS-L011206.

Table 2a : Respondents' Level of acceptability on improved cassava varieties

\begin{tabular}{|c|c|c|}
\hline Improve cassava varieties & Acceptable & Not acceptable \\
\hline Yellow cassava (vitamin A) & $89(80.9)$ & $21(19.1)$ \\
\hline NR 03/0211(improved local) & $98(89.1)$ & $12(10.9)$ \\
\hline TMS 30555 improved & 12(10.9) & $98(89.1)$ \\
\hline Molekanga (local) & $110(100.0)$ & $0(0.0)$ \\
\hline TMS01412(improved local) & $110(100.0)$ & $0(0.0)$ \\
\hline Black cassava (Ege Dudu) & $98(89.1)$ & $12(10.9)$ \\
\hline TME 419 Improved variety & $55(50.0)$ & $55(50.0)$ \\
\hline TMS 3000 (improved) & $20(18.2)$ & $90(81.6)$ \\
\hline TMS30110 (improved) & $32(29.1)$ & $78(70.9)$ \\
\hline TMS 30572 (improved) & $0(0.0)$ & $110(100.0)$ \\
\hline UMUCASS 42 & 12(10.9) & $98(89.1)$ \\
\hline UMUCASS 43 & $10(9.1)$ & $100(90.9)$ \\
\hline IITA-TMS-L982132 & $98(89.1)$ & $12(10.9)$ \\
\hline IITA-TMS-L011206 & $88(80.0)$ & $22(20.0)$ \\
\hline CRI-Lamesese & $12(10.9)$ & $98(89.1)$ \\
\hline CRI-Abrabopa & $0(0.0)$ & $110(100.0)$ \\
\hline AGRA-Bankye & $0(0.0)$ & $110(100.0)$ \\
\hline CRI-Amansan Bankye & $20(18.2)$ & $90(81.8)$ \\
\hline
\end{tabular}

Source field survey, 2018

Tables 2b Categorization of respondents based on level of acceptability of improved cassava varieties.

\begin{tabular}{lcc}
\hline Variable & Frequency & Percentage \\
\hline High & 43 & 39.0 \\
& \\
& \\
& http://dx.doi.org/10.31364/SCIRJ/v6.i10.2018.P1118584 \\
&
\end{tabular}


Low

Total

110

100.0

Source field survey, 2018

\section{Respondents' Constraints militating against acceptability of improved cassava varieties}

By categorization in table $3 \mathrm{~b}$, majority $61.8 \%$ of the respondents had high response based on constraints militating against acceptability of improved cassava varieties.

Result of analysis in table 3 showed constraints facing by respondents on acceptability of improved cassava varieties in the study area. Majority (100.0\%) had severe constraint on inadequate extension contact, $(89.1 \%)$ had high cost of transportation, High cost of cassava tubers, Lack of fund /capital and percentage of water content on cassava tubers. (82.7\%) had preferences of varieties cassava tubers while only $(50.9 \%)$ had not a constraint on Colour variation.

Table 3: Respondents' Constraints militating against acceptability of improved cassava varieties

\begin{tabular}{lccc}
\hline Constraints & Severe Constraints & Mild Constraints & Not a Constraint \\
\hline Inadequate extension contact & $110(100.0)$ & $0(0.0)$ & $0(0.0)$ \\
High cost of cassava tubers & $98(89.1)$ & $12(10.9)$ & $0(0.0)$ \\
Pest and diseases problem & $36(32.7)$ & $74(67.3)$ & $0(0.0)$ \\
Preference of varieties cassava tubers & $91(82.7)$ & $19(17.3)$ & $0(0.0)$ \\
Percentage of water content on cassava tubers & $98(89.1)$ & $0(0.0)$ & $12(10.9)$ \\
Lack of fund /capital & $98(89.1)$ & $0(0.0)$ & $12(10.9)$ \\
Tuber size & $7(6.4)$ & $78(70.9)$ & $25(22.7)$ \\
Colour variation & $0(0.0)$ & $54(49.1)$ & $56(50.9)$ \\
\hline
\end{tabular}

Source field survey, 2018

Tables 3b: Categorization of respondents' constraints militating against acceptability of improved cassava varieties.

\begin{tabular}{lccc}
\hline Variable & Frequency & Percentage & Mean \\
\hline High & 68 & 61.8 & 15.1 \\
& & & \\
Low & 42 & 38.2 & \\
Total & $\mathbf{1 1 0}$ & $\mathbf{1 0 0 . 0}$ & \\
\hline
\end{tabular}

Source field survey, 2018

Hypothesis: test of relationship between Socio-economic characteristics of the respondents and acceptability of improved cassava varieties. 
This hypothesis was tested with the aid of Chi-square. Result of analysis in table 4 showed that there is no significant relationship between Socio-economic characteristics of the respondents and acceptability of improved cassava varieties except Sex $\left(\mathrm{X}^{2}\right.$ value $=$ 7.137, P- value $=0.028$ ) which is significant. This implications that sex of the cassava processors influenced their level of acceptability of improved cassava varieties.

Table 4: Chi-square analysis of relationship between Socio-economic characteristics of the respondents and acceptability of improved cassava varieties.

\begin{tabular}{lcclc}
\hline Variable & $\mathbf{X}^{2}$-value & P-value & Decision \\
\hline Age & 1.260 & 0.533 & NS \\
Sex & 7.137 & 0.028 & $\mathrm{~S}$ & $\mathrm{NS}$ \\
Education status & 1.109 & 0.574 & $\mathrm{NS}$ \\
Religions & 1.109 & 0.574 & $\mathrm{NS}$ \\
Household size & 2.648 & 0.266 & $\mathrm{NS}$ \\
Years of experience & 1.112 & 0.573 & $\mathrm{NS}$ & \\
Income & 0.267 & 0.875 & &
\end{tabular}

Source field survey, 2018

\section{Conclusion and Recommendations}

Majority of the respondents in the study area were females in there active age, married and their education status were very low. Acceptability of the respondents on improved cassava varieties was low in the study area

The study thus, concludes that based on the empirical findings of this study, the following recommendations are made;

Extension services on improved cassava varieties should be intensified in the study area by offering services. Moreover, information sources are very important in creating awareness of agricultural Production in general and improved cassava varieties in particular. Such information especially if transmitted in local languages would definitely encourage full acceptability improved cassava varieties in the study area.

\section{Reference}

1. Abdoulaye, T., Abbas, A., Maziya-Dixon, B., Tarawali, G., Okechukwu, R., Rusike, J., Alene, A., Manyong, V. and Ayedun, B. (2014): Awareness and Adoption of Improved Cassava Varieties and Processing Technologies in Nigeria. Journal of Development and Agricultural Economics. 6 (2): 67 - 75.

2. Adebayo K., Anyawu, A.C and Osiyale, A.O. (2003): Perception of Environmental Issues by Cassava Processors in Ogun State, Nigeria-Implications for Environmental Extension Education. Journal of Extension system. 19:103-112.

3. Bakut, P. M. (2013): Factors Influencing Adoption of Recommended Cassava Production Practices by farmers in Bwari and Kuje Area councils, Abuja, Federal Capital territory. An unpublished M.Sc Thesis submitted to the Department of Agricultural economics and rural sociology, Ahmadu Bello University, Zaria, 
Nigeria. pp. 57.

4. Food and Agricultural Organization (FAO) (2004): Corporate Document Repository. The

GlobalCassavaDevelopment Strategy. Retrieved April 16, 2013 from

http://www.fao.org/docrep007/ji255e00htm.

5. Food and Agricultural Organization (FAO) (2005): Corporate Document Repository. A Review of Cassava in Africa with Country Case Studies on Nigeria, Ghana, the United Republic of Tanzania, Uganda and Benin. Retrieved August 20, 2013from http://www/fao.org/./ao15e06.htm.

6. Food and Agricultural Organization (FAO) (2014): Food outlook: Biannial report on global foodmarkets.Food and agricultural organization. P 32-37

7. Odebode S. O. (2008): Appropriate Technology for Cassava Processing in Nigeria; User's Point of View. Journal of International Women Studies. 9 (3): 213-225.

8. Odii, O. C. (2012). Socio-Economic Evaluation of Cassava Production by Women farmers in Igbo-Eze North Local Government Area of Enugu State, Nigeria. International Journal of Agricultural Science, Research and Technology. 2 (3): 129-136.

9. Okoye AA (1989): Factors Affecting Adoption Process by Farmers in Selected L.G.A of Anambra State. J. Agric. Soc. Niger. pp. 124-127.

10. Suleman, A. (2012): Factors Influencing Adoption of Improved Cassava Processing Technologies by Women Processors in Akoko-Edo Local Government Area of Edo State Nigeria. Unpublished M,Sc Thesis. Department of AgriculturalEconomics and Rural Sociology, Faculty of Agriculture, Ahmadu Bello University Zaria.

11. Sofoluwe, N. A., Tijani, A. A. and Baruwa O. I. (2011): Farmers Perception and Adaptation to Climate Change in Osun State, Nigeria. African Journal of Agricultural Research 6 (20): 4789-4794. 